\title{
INTERNATIONAL ECONOMIC RELATIONS: STRATEGIC TRENDS
}

\section{МЕЖДУНАРОДНЫЕ ЭКОНОМИЧЕСКИЕ ОТНОШЕНИЯ: СТРАТЕГИЧЕСКИЕ ТЕНДЕНЦИИ}

\section{Vladimir Shedyakov ${ }^{1}$}

DOI: https://doi.org/10.30525/978-9934-588-15-0-45

Abstract. Subject of research is the strategic transformation of international economic relations. Changing the balance of factors and the scale of opportunities and risks for humanity brings this topic to the forefront of social science analysis. The methodology of conducting and presenting the results of the research in the text is based on practical and theoretical developments in the field of, firstly, the correlation of strategy, tactics and operational art; secondly, on the characterization of the vector of changes in international relations; thirdly, on the identification of the main features of new social trends; fourthly, on solving the tasks of developing cooperation, solidarity, mutual trust as the basis for the emergence and ordering of economic relations and, finally, fifthly, on the analysis of the possibilities of a productive regulatory impact on their decision with emerging innovation experts to optimize decision-making. Accordingly, the objective of the article is to highlight the significant characteristics of the strategic transformations of international economic relations. The purpose of the text is to sum up the intermediate results of studying possible consequences and to identify ways of effective influence on global processes. For this, the features of new processes in the international economy are determined. Possible differences of variants depending on the subjects of the "assembly of the future" are shown. The short, medium and long term effects of transformations are being examined. In the context of the study of the essence, forms, opportunities and risks of the internal control loop, the processes of cooperation / partnership are highlighted. The characteristics of the new structuring of the international polylogue (in particular, in the

\footnotetext{
${ }^{1}$ free-lance, Dr. Sc. (Sociology), Ph. D. (Economics), Ukraine 
economic planes) are presented through the prism of strategic competition. In the effective achievement of the result of organizational and managerial changes, information resources of strategic interaction have been allocated. Thus, the formation and realization of an effective post-modern security strategy and the development of society presupposes a flexible combination of the use of traditions and innovations, objective and subjective factors, cyclically undulating and uniquely irreplaceable processes, general patterns and specifics of conditions (primarily, risks and opportunities), in optimizing measures which increase the value of the increment, distribution and use of knowledge. The analysis of the processes of socio-economic development is carried out through the prism of the relations of strategic competition and partnership, which are consolidated by the historical series of over-projects of the cultural and civilizational worlds. Accents in resource and methodological bases of influence shifted in favour of the military-political, then economic, then organizational-management strategy, reinforcing the sound of the information component. The tendencies of humanization and democratization of the structuring of social communications inevitably bring to the forefront of information relations their social level, which is closely connected with the basic value-sense complexes of the cultural and civilizational worlds. The results of strategic competition in enhancing the role of the knowledge society raise the importance of the development and implementation in the pro-social areas of the scientific and intellectual potential. The quality of both personal education and participation in learning processes (as well as self-study and retraining) is associated with increased requirements for social pedagogy and social management. Thus, the results of the study, summarized in the text, can be used both to improve organizational and management practices during participating in changing international economic relations, and to further understand the topic as part of the teaching of university courses.

\section{1. Вступление}

Экономический, морально-политический и прочие аспекты взаимодействия (в частности, противостояния) - важнейшие факторы выбора собственно военных стратегии и тактики. Их единство - условие эффективности военно-технического потенциала. Соответственно, «гибридность» - элемент стратегической культуры. Развёртывание 
многослойных трансформаций (среди которых есть и кардинальные) требует повышения культуры сочетаний стратегий, тактики и оператики при принятии и осуществлении организационно-управленческих решений. Глобальные процессы имеют системный характер. Они охватывают народы безотносительно субъективного желания и понимания логики процессов. Вместе с тем, умение выделить и усилить главные направления - необходимость продуктивных решений, в частности - как полноценного участия в «сборке будущего», так и сознательного целенаправленного использования обновляющейся среды в интересах своего народа. При этом сегодня всё более заметное значение приобретают информационные операции, тесно связанные с киберсиловыми возможностями сетевых организаций и состоянием социальных коммуникаций.

Зачастую именно изучение тенденций открывает возможность успешной реакции, в том числе - на уровне организационно- управленческих отношений. Серьёзные изменения таких факторов, как стабильность социально-экономической, природно-климатической и материально-технической среды, характер структурирования субъектов решений, прогнозируемость точек развития и т.д. - требуют весомых ответов в подготовке и реализации воздействий. Гегемония как навязывания всей ойкумене наличными силами и средствами: военными, дипломатическими, культурными, мировоззренческими и т.д. - удобных для себя и воплощения интересов своей страны порядков. При этом и сами технологии выработки и проведения организационно-управленческих решений являются одним из определяющих факторов активизации культурно-цивилизационный миром своего потенциала. Соответственно, во время форсированных трансформаций организационно-управленческие отношения способны оказать весомое воздействие на соотношение конкурентоспособности политико-экономических субъектов.

Теоретико-методологическими основаниями исследования стали разработки в вопросах, во-первых, понимания соотношения стратегии, тактики и оператики (прежде всего, П. Батова, М. Бонч-Бруевича, А. Брусилова, А. Василевского, Н. Ватутина, А. Воеводина, Н. Воронова, Л. Говорова, Н. Головина, А. Горбатова, А. Гучкова, А. Деникина, М. Драгомирова, М. Дроздовского, А. Егорова, А. Жомини, Г. Жукова, А. Игнатьева, А. Каледина, В. Каппеля, К. Клаузевица, А. Кокошина, 
И. Конева, Л. Корнилова, Г. Леера, Э. Люттвака, Р. Малиновского, С. Маркова, К. Мерецкова, Д. Милютина, Х. Мольтке, Н. Огаркова, К. Рокоссовского, П. Румянцева, Р. Свечина, А. Снесарева, М. Скобелева, А. Суворова, Сунь Цзы, Ф. Ушакова, М. Фрунзе, Б. Шапошникова), во-вторых, характеристики вектора изменений международных отношений Ж. Алфёровым, Ж. Аттоли, Э. Бабиным, У. Беком, Г. Бехманном, А. Богатуровым, А. Бузгалиным, В. Букреевым, А. Бутенко, В. Вазюлиным, И. Валлерстайном, В. Геецем, Э. Гидденсом, С. Глазьевым, Л. Градобитовой, А. Гринспеном, А. Громыко, Ф. Дваири, А. Дугиным, А. Дынкиным, А. Зиновьевым, А. Иголкиным, Э. Ильенковым, Д. Калаичем, С. Карагановым, М. Кастельсом, А. Киреевым, А. Колгановым, А. Коробкиным, С. Кургиняном, Х. Маккиндером, Л. Максимовой, С. Миллером, С. Михеевым, В. Мотылёвым, И. Носковой, К. Овчинниковым, А. и И. Панариными, С. Платоновым, Е. Примаковым, В. Пякиным, В. Рыбалкиным, М. Смитом, Н. Стариковым, Б. Супруновичем, Дж. Урри, Ж. Фреско, Р. Хасбулатовым, К. Хаусхофером, С. Хелемендиком, Ф. Хоффманом, М. Хрусталёвым, Н. Черкасовой, К. Шмиттом, в-третьих, выделения основных черт новых тенденций общественной жизни Е. Авдокушиным, С. Бартеневым, А. Белорусовым, Е. Брагиной, А. Булатовым, С. Бэнноном, В. Виноградовым, Р. Волковым, Э. Гэмблом, М. Делягиным, В. Дрожжиновым, Ю. Дроздовым, В. Ефимовым, В. Железновой, Л. Ивашовым, М. Ильиным, В. Иноземцевым, Е. Касаткиной, В. Колесовым, Дж. Корбином, И. Коротченко, Дж. Куртом, М. Лебедевой, В. Ломакиным, А. Ляменковым, М. Маляровой, И. Острецовым, М. Осьмовой, В. Паньковым, С. Пенкиной, Н. Платошкиным, В. Пресняковым, В. Роговым, Б. Сандерсом, В. и Н. Сапичами, К. Семёновым, А. Семченко, Е. Талызиной, П. Цыганковым, В. Чекуровым, О. Четвериковой, в-четвёртых, практико-теоретических решений задач развития кооперирования, солидарности, взаимодоверия как основы возникновения и упорядочения экономических отношений Н. Бухариным, Н. Верещагиным, П. Кропоткиным, П. Лавровым, С. Лугининым, С. Масловым, Н. Рыбниковым, А. Рыковым, М. Туган-Барановским, А. Хомяковым, А. Чаяновым, А. Челинцевым, и, наконец, в-пятых, на анализе возможностей продуктивного регулятивного воздействия на их решение с применением появляющихся инноваций В. Большаковым, Дж. Гэлбрей- 
том, А. Денисовым, С. Кара-Мурзой, В. Катасоновым, С. Кравченко, В. Лефевром, С. Переслегиным, К. Петровым, У. Ростоу, В. Сагатовским, Е. Спицыным, С. Ураловым, П. Фейерабендом, А. Фурсовым, М. Хазиным а также в работах «Корпоративная стратегия» И. Ансофа, «Современный стратегический анализ» Р. Гранта, «Стратегический анализ политики» Э. Ожиганова, «Конкурентная стратегия» М. Портера, «Стратегический менеджмент» А. Томпсона и Дж. Стриклэнда, «Стратегия и планирование» Д. Хасси, «Концепция корпоративной стратегии» К. Эндрю, иных специалистов в оптимизации управленческих решений (Б. Ананьев, А. Васильева, И. Ворожейкин, Н. Гришин, А. Дынкин, М. Линдгрен и Х. Бандхольд, Дж. Малган, С. Петров, С. Степанов, Д. Фридман и др.). На этой основе задача текста - выделение значимых характеристик стратегических трансформаций международных экономических отношений.

\section{2. Межпарадигмальные международные} экономические отношения: между прошлым и будущим

Формирование и осуществление эффективной постсовременной стратегии безопасности и развития общества предполагает гибкое сочетание использования традиций и инноваций, объективных и субъективных факторов, циклично-волнообразных и уникально-невосполнимых процессов, общих закономерностей и специфики условий (прежде всего, рисков и возможностей), в оптимизации меры которых возрастает значение приращения, распространения и использования знания. Постсовременный продуктивный капитал формируется вокруг творческих возможностей и интеллектуального потенциала человека, их организации и использования. Наиболее общественно полезной деятельностью постглобального мироустройства становится творческая (прежде всего, духовно-интеллектуальное творчество): после волн механизации, автоматизации, роботизации и т.д. лидеры, как известно, создают смыслы, удел аутсайдеров - множить вещи. Перенос на уровень автоматов мускульных и энергетических функций повышает ценность (а, стало быть, вес как фактора конкуренции) собственно творческого потенциала человека, прежде всего, духовно-интеллектуального творчества. Вместе с тем, века разграбления колоний ставят под серьёзное сомнение добропорядочность и, следовательно, 
легитимность нынешних активов бывших метрополий. Использование недобросовестной конкуренции, торговых войн и санкционной политики также подрывает принципы свободы перемещения товаров и капиталов, а под объявленным изоляционизмом зачастую легко прочитывается элементарный эгоцентризм. Сторонниками фритредерства и снятия препон в международных экономических отношениях всегда были страны-лидеры, получавшие от этого наибольшие выгоды, тогда как протекционизм защищался уязвимыми на данном этапе государствами. Однако и постглобальная среда создаёт возможности соединить преимущества интеграции в мировое хозяйство с защитой своеобразия базовых ценностно-смысловых комплексов, закладывающих ось идентичности культурно-цивилизационного мира, и время концентрированной переходности потворствует разнообразию. Вместе с тем, одной из форм эгоцентризма у скопивших наибольшие богатства становится единство выдвижения ими подходов самоизоляции и обоснования своих «прав» на навязывание собственной воли и удобного для себя миропонимания.

Призывы к следованию единообразию модели исключительно либерально-демократического устройства всё чаще обнаруживают под собой претензии на глобальную гегемонию с целью использования чужих ресурсов без ответственности за это. С одной стороны, продуктивные идеи, питавшие классическую либеральную демократию, вошли во многие иные идеологические системы. С другой стороны, под жупелом либерализма порой пытаются навязывать тоталитарность порядка (как правило, основанного на западных подходах). При этом, зачастую, попытки его воссоздания оказываются неэффективными и приводят к перерасходу ресурсов (включая человеческий). Соответственно, она оказывается формой без содержания и оппонируется (прежде всего культурно-цивилизационными мирами) со стороны как набирающих силу регионов, так и государств - субъектов международных процессов. Указания на абстракции 19 в.: свободную конкуренцию, частную собственность, человека экономического заметно противоречат нынешним реалиям. Отсутствие практических и теоретических аргументов у эпигонов либерализма приводит к деградации рекомендаций, пошлому самоповтору мантр из иного времени и других условий при нежелании мириться с реальностью осуществлённых 
и происходящих изменений. К примеру, процессы социализации производства, распределения, обмена и потребления постсовременного уровня, с одной стороны, для поддержания своей конкурентоспособности предполагают широкое задействование инструментария маркетинга, что означает производство отнюдь не на неизвестный рынок, где только и устанавливается общественная цена предмета или услуги, выявляется объём потребности в них. С другой стороны, продолжается сегментация и усиливается производство под потребительские склонности конкретных групп. То есть социализация жизнедеятельности проявляется не только в стандартизации, но и в индивидуализации воспроизводственных процессов.

Прежняя западная модель общественного устройства и миропорядка исчерпала себя. Тем паче беспочвенно и нереалистично стремление стран из бывшего «лагеря реального социализма» попасть в «золотой миллиард». На переломе межпарадигмального уровня «каждый сам вытаскивает себя за волосы из болота». При этом с одной стороны, секрет успеха народа - в привязке общих тенденций к своим конкретным условиям. С другой, кардинальное значение приобретает соединение государственного управления с местным самоуправлением в принятии от населения рутинно-бытовых проблем для расковывания просоциального вектора творческой активности народа. Разумеется, условиями этого становится создание условий как трудовой детерминанты благополучия и социального статуса, так и восстановления практической реализации представлений о справедливости порядка. Таким образом, ценностно-смысловые комплексы прямо проявляют себя как остов информационного противостояния. Соответственно, недобросовестная конкуренция может подталкивать к попыткам (в частности, методами «разноцветного бархата») расшатать нравственные устои народа, его табу и систему представлений, внедряя разнообразные информационные вирусы.

Кардинальное усложнение технико-технологической и социально-экономической среды, расширение поля нравственно-духовного выбора и появление ядерного оружия (в частности, как фактора возмездия) - весомые трансформации условий внешнего взаимодействия. Одновременно выход на уровень безальтернативной ценности индивидуальной одарённости требует для развития и безопасности 
общества обеспечить просоциальные развёртывание и реализацию максимального объёма задатков, что предполагает поиск органичных для конкретного культурно-цивилизационного мира форм сочетания государственных гарантий (прежде всего, равноправия в обладании благ и возможностей) с личной инициативой. Другими словами, речь идёт об укреплении (и обновлении) механизмов интеграции общественных и индивидуальных начал. Разумеется, уже система реального социализма на протяжении 20 века стимулировала поиски путей построения более справедливого устройства общества, наполняла корзину социальных, экономических, политических, экологических и т.д. прав и свобод человека, защитила от уничтожения империализмом метрополий т.н. «развивающихся стран». Вместе с тем, откровенно грабительский (часто - вплоть до геноцида аборигенов) характер накоплений в метрополиях: капитализм требовал роста рынков - транснациональные корпорации всячески лоббировали приращение поля своего капитала - империализм становился главенствующей формой политического курса, - автоматически вызывает вопрос о легитимности результатов империалистического грабежа. В нынешних же условиях рост справедливости и имущественной однородности общества - непременное условие использования личной одарённости наибольшего числа людей в качестве стимула дальнейшего общественного прогресса.

В процессе развёртывания нового регионализма средства, ресурсно-методологические базы осуществления жизнедеятельности сами создают подлинную цель, которая может и не соответствовать декларируемой. Одновременно, эпоха создаёт условия расширения диапазона ресурсных баз и изменения методологии использования стратегий, которые ориентированы не столько на участие в изнурительной конкуренции (в частности, в информационном противоборстве и «контрпропаганде»), сколько на взаимодействие в потоке событий, где каждый не имеет полноты информации и зависит от действий других акторов-контрагентов. Конфронтационный настрой только помогает формированию и закреплению в ответ также враждебной реакции, требует дополнительных усилий для навязывания своей стратегии; действие рождает противодействие. В то же время трансформируется восприятие воображения в интерпретации агрессивных действий, 
форм и их целесообразности, «гибридности» и превращённости. Вооружённое противостояние вообще перестает быть существенной чертой войны, тем более - эффективным методом борьбы и средством навязывания условий интеграции. Зачастую, если удалось втянуть в состояние агрессии, значит, вы уже проиграли. Выигрыш - за «организатором», определяющим образом влияющем на процессы, отношения, поведение людей.

При этом полиструктура мирохозяйственных связей как целостность, основанная на выработанных и взаимоприемлемых нормативах отношений, а вовсе не блок из идентичных атомов-элементов, приобретает вид формируемой действительности. Ни одна система ценностей в моделях развития и постглобального структурирования, ни один из вариантов жизнеустройства уже не могут рассматриваться как абсолютно оптимальные и нормативные для всего человечества [1-3]. Исчезает понятие периферийной культуры: они равноценны и равноправны. В этом контексте и само понятие развития нуждается в обновлении: кроме стабильного и сбалансированного роста, оно должно ориентироваться на такие максимы как солидарность, свобода выбора, убеждений и слова, терпимость. Причём происходят изменения не только отдельных социально-политических институтов, но и всей культурной среды, отношений, структур. Так что мировые трансформации имеют гораздо более кардинальный характер. Ныне парадигмальность перехода заключается в более существенном дрейфе, нежели движение от преобладания одной модели жизнеустройства к другой. Дело в отказе от представлений об оптимальности какой-либо модели. Соответственно, - о переходе от конкуренции в овладении единственной модели к состязанию разнокачественных подходов.

Переход к, к логике свободы является, одновременно, отказом от единственности любого базиса развития. Постглобальное структурирование международной жизни связано не с навязыванием одного, удобного для фиксации состояния и перспектив какого-либо отдельного актора, мировоззрения, принципов и подходов, а с сосуществованием и конкурированием совершенно разных вариантов обеспечения своего общежития. Соответственно, универсализм подходов остаётся в прошлом. При этом возникновение новых систем сдержек и противовесов происходит путём многочисленных конфликтов, стимулирующих рас- 
ползание хаоса. Разумеется, постглобальный мир строится как совокупность взаимозависимых, но кардинально разных культурно-цивилизационных миров - макрорегионов. Вместе с тем, содержательная, а не формальная («как картофелины в мешке») взаимозависимость связывает именно взаимодополняющие, значит различающиеся, а не тождественные образования. Т.о. постсовременная модернизация приводит к формированию уже глобально соотносимого, но регионального по своему существу структурирования. Полицентризм и ризомичность развития заведомо отрицают и единственность «точки сбора» будущего, и общность модели развития. Формируется ряд взаимодействующих (партнёрски и конкурентно) центров, каждый из которых культивирует удобные для себя варианты структурирования общественной жизни. В обществе знания каждый ответственно делает свой выбор и никто никому ничем не обязан; что неизмеримо поднимает планку требований к нравственности и верности традициям, а, значит, методологии образования и управления. В сложившейся ситуации методология стимулирования желательных изменений составляет адекватный условиям и эпохе регулятивный принцип постсовременности. Между тем, переживание собственного падения как общей катастрофы зачастую провоцирует на истеричные реакции и подталкивает к нерациональным решениям. Реальное осознание ответственности за сохранение планеты и развитие человечества противостоит раскачке международных отношений как в сфере глобальной безопасности, так и в других измерениях жизни. Тем самым в число важнейших для ойкумены задач выходит формирование условий полифонии подходов, полилога акторов при признании их самоценности и равноправия. В свою очередь, это означает необходимость и укрепления рычагов, вынуждающих к выполнению принимаемых на себя обязательств, и признание верховных прав на вмешательство (военное, экономическое, гуманитарное и т.д. - в частности, введение каких-либо санкций) исключительно за ООН с её Советом Безопасности, а также формируемых совокупностью воль национальных представительств организаций (типа ВТО). Недопустимы ни игнорирование чужих (пусть и вполне правомерных) интересов, ни саботаж демократических механизмов взаимодействия, ни применение мер недобросовестной конкуренции (например, запугивание, подкуп и устранение неудобных для себя лидеров других стран, а то и путчи). 


\section{3. Кооперирование как условие развития}

Осуществление многоуровневого взаимного кооперирования - фактор превращения социальности в средство развития, позволяющее, в том числе и подъём гармоничной персональной одарённости, а также социальной и индивидуальной творческой активности. Именно надиндивидуальные, надэгоистичные и другие трансцендентные факторы, объединённые и структурированные Сверхпроектом, часто оказываются решающими на макро- и микроуровне. Освоение каждого нового уровня в высвобождении энергии индивидуальной и социальной творческой активности приводило к историческим свершениям. Нынешние формы их структурирования часто рассматриваются сквозь призму социального партнёрства и производственного народовластия / демократии (на микроуровне) и в приобретении качества равноправного взаимодействия целостных и самоценных полиструктур культурно-цивилизационных миров (на макроуровне). Вместе с тем, именно качество и направленность взаимозависимости, а также её механизмы и субъектность оказываются в эпицентре международных противостояний переходного времени.

Тенденции осуществления стратегических метаморфоз вне зависимости от осознания и умения отражения их особенностей народами и их лидерами требуют изменения качества взаимодействия: как на внутреннем, так и на внешнем контурах структурирования. Трансформации воплощения (прежде всего, в системе информационных взаимодействий) идеального, надиндивидуалистичного понимание человека и общества. Под иллюзией же верховенства потребительских интересов каждого легко заметна жёсткая и предельно отчуждённая воля «техноструктуры», которая пытается задать индивидам их потребительский (редуцированный к биологии) стереотип [4-7]. А распад личности до уровня индивида, доминирование биологического над социальным, торжество звериных инстинктов - это, собственно, и есть деградация человека и культурно-цивилизационного мира. Соответственно, прогресс - в восхождении от «человека экономическому» к «человеку творческому». Регресс - в деградации до биологических инстинктов и состояния «экономического животного», «человека умелого», с индивидуальной редукцией до звериных инстинктов и общественной атомизации - стимулируется средой «сумеречного сознания», 
ориентирующей на потребительство и накопительство, отвергающей сущностные силы человека в пользу фетишизации вещей и капитала. Обстановка утраты чётких мировоззренческих ориентиров, нарастание потоков иррационализма и квазидуховной жизни (от распространения лженаук до подрыва традиционной веры) способна поколебать ценностную опору культурно-цивилизационного мира, став важным направлением его соскальзывания из состояния субъекта геостратегии к положению мировой периферии и качеству объекта внешнего манипулирования. Однако человечество уже исчерпывает потенциал прежнего типа развития, базировавшегося на стремлении к безграничному хозяйственному экстенсивному росту, требовавшего повышения неравномерности социальных возможностей, экспансии на новые рынки и, следовательно, постоянства потребительского угара и военных авантюр. Уперевшись в непреодолимую преграду угрозы всему живому от устаревающих стратегий, человечество и вынуждено, и имеет всё необходимое, чтобы переходить к акценту на интеллектоёмкие экологичные естественно-природные технологии с приоритетом уважения к окружающей среде и гуманизации общества. Вместе с тем, и прогресс может нести в себе некоторые черты регресса - и наоборот.

Соответственно, новые горизонты развития открываются тем государствам, в которых общественное устройство максимально способствует реализации творческого (прежде всего, интеллектоёмкого) потенциала каждого, а Сверхпроект может консолидировать, структурировать и мобилизовать на решение созидательных задач. При этом государство обязано обеспечить максимально высокие социальные стандарты жизни и условия творчества (в частности - за счёт организации решения вместе с территориальными общинами рутинно-материальных, бытовых вопросов), предотвращения растрачивания способностей в бессмысленных гонках потребительства / стяжательства. Вместе с тем, рост бережного отношения к разномыслию как непременному атрибуту творческого поиска становится важным следствием расширения корзины прав и свобод личности. При этом, с одной стороны, участие в общественно полезной деятельности само по себе должно приносить не только удовлетворённость и чувство собственного достоинства, но и всестороннее благополучие с социальным признанием. С другой стороны, только различия в одарённости и твор- 
ческого воплощения её может быть признано законным основанием неравенства.

Таким образом, для расширения массива развития и реализации духовно-интеллектуального творчества государство вкупе с местным самоуправлением:

1) берёт на себя (вкупе с местным самоуправлением) как удовлетворение первичных потребностей каждого, так и выполнение рутинных обязанностей и функций (прежде всего, в производственной и коммунально-бытовой сферах);

2) отсекает устарелые формы фетишизма (товарно-потребительского и капитально-стяжательского);

3) создаёт заслоны перед возможным нарастанием абсолютного и относительного обнищания масс, а также перед нетрудовыми формами обогащения, социальной, в частности имущественной, поляризации.

\section{4. Экономика полилога: новые рубежи}

Возможные и эффективные реакции социальных организмов под влиянием сырьевой и производственной базы, экономической географии своего пространства, исторической памяти, отечественного наследия и других факторов складываются в организационно-управленческие предпочтения. В культурно-цивилизационном мире как целостности кардинально расширяются объективные основания для повышения многоуровневого разнообразия. Усиливает общественное звучание формула «творческая многоликость - жизнь, единообразие уродование в прокрустовом ложе и смерть». Живое противоречиво, через разрешение противоречий осуществляется развитие. Отсутствие противоречий -признак остановки, но и антагонизм может грозить аннигиляцией. Вместе с тем, усложняется организационно-управленческую подготовка деятельности, перенося акценты на стимулирование и обеспечение: в частности, при реализации этапов «воспринимать новое для выделения закономерного и случайного, повторяемого и уникального», «обеспечить своевременные приток и обработку информации как предпосылку знания», «знать, чтобы понимать», «понимать для осознанных принятия и осуществления решений» [8-12]. Причём изменения по-разному сказываются в кратко-, средне- и долгосрочной перспективе. 
Соответственно, необходимо переходить от привычки к навязыванию глобальных стандартов крайне разнородным культурно-ценностным мирам к ориентации на культивирование собственных условий продуктивности и долговременной стабильности жизнедеятельности. Вместе с тем, заведомо должны быть исключены стратегии социально-экономического оздоровления, несущие риски ухудшения качества жизни широких слоёв или социально-демографических показателей. Естественно, что именно инновационно-синергетические свойства постмодернистского управления резко усиливают роль игрового характера и социальных сетей в коррекции общественных отношений, в т.ч. - на институциональном уровне.

Так, всякий культурно-цивилизационный мир создаёт свой диапазон продуктивных организационно-управленческих решений. Наряду с этим, усиливается роль внегосударственных образований, порой - наднационального уровня; это уже не только индивидуальные или семейные империи, но и разнообразные МНК / ТНК, а также неправительственные / неприбыльные организации. При этом распространёнными чертами трансформирования явно становится при этом единство: общей и частной заинтересованности, общественного и личного интереса, социализации и индивидуализации, верности прошлому и устремленности в будущее, общественно важных традиций и инноваций, нравственности и интеллектуальности, ресурсно-методологических баз Традиции, Модерна и Постмодерна, своего и чужого, протекционизма и фритредерства, открытости и закрытости, мотивирующей общественной среды и кластеров - драйверов развития, элиты и народа, демократии-аристократии и меритократии-экспертократии, стратегии, тактики и оперативного искусства изменений. В свою очередь, усиление тенденций постглобализации ойкумены сопряжено с перестройкой как устоявшейся практики международных отношений, так и привычных представлений о нормативном мироустройстве, повышая градус конкуренции [13-16].

Сверхпроект проявляется общественной средой и локомотивами эпохи, в нашем случае - научно-образовательно-производственными кластерами. Сегодня наиболее острое противоречие - это антагонизм в реализации созданной базы, которая может использоваться либо для радикальной гуманизации жизни в интересах всего живого, либо для 
эффективного манипулирования, что и проявляется в противостояниях интересов основных масс народа и олигархата. Одним же из острейших противоречий, проявляющихся посредством сонма конфликтов, становится противостояние ценности собственной самобытности (в частности, творческого саморазвития и самоосуществления) и обладания (подчинения, манипулирования). Принадлежность к доминированию каждой из них генерализирует, выстраивает дерево целей интересов, функционально-ролевую системность. Применение этих стратегий может быть использовано для успеха и преуспевания либо своего культурно-цивилизационного мира, либо себя, быть ориентировано на социальные или антисоциальные (и асоциальные) задачи. В любом случае, во-первых, если не иметь и не реализовывать стратегии собственного Сверхпроекта, то превращаешься из субъекта процессов в объект внешнего манипулирования. Во-вторых, обеспечение приемлемого качества жизни населения, хозяйственного успеха и долгосрочного стабильного развития в информационную эру возможно только на основе комплексного подъема и обеспечения условий востребованности научно-образовательного комплекса. Соответственно, его состояние становится и решающим фактором преображения экономики и общества: на первый план выходит состязание в получение доступа к критическим ресурсам жизнеобеспечения развития и технологиям их использования в экономике культурно-цивилизационных миров, включая контроль за миграцией экономически активного населения (особенно - носителей интеллектуально-творческого потенциала, прежде всего, учёных, изобретателей, одарённых студентов), качеством и доступностью образования, трансфертом инноваций и проч. Вместе с тем расширилась возможность, живя на одной территории, обслуживать своей деятельностью интересы иной. Собственно, поиск, выдвижение и поддержание Сверхпроекта развития своего культурно-цивилизационного мира в соответствии с логикой истории и возможностями её применения в конкретном контексте, обеспечение приоритета ключевых направлений - это и составляет основное содержание деятельности элиты. Причём никакая группа топ-менеджеров не может быть «независимыми демиургами», никакое агрессивное меньшинство не имеет права подменять волю и коренные интересы народа а с каждой новой контролирующей инстанцией дополнительно 
мультиплицируются общественные отношения, в свою очередь выходящие из-под контроля. А для предохранения от саморазрушительных и губительных для мира сил интеллектоёмкие формы материального и духовного производства должны прочно покоиться на фундаменте нравственности. И важным фактором становления социокультурного простора является Сверхпроект развития, рождающий чувство сопричасности и гордости за совместные общественные свершения, а также позволяющий как найти своё место в нём, так и осуществлять развитие своих сущностных сил. При этом, например, даже ради высоких социальных стандартов (тем более - узкокорыстных интересов некоторых групп) нельзя подрывать потенциал сверхзадачи, прорыва к развитию в дальнейшем. Люди должны получить условия для достойной жизни и самореализации, чтобы не ориентироваться на отъезд вовне, а связывать своё будущее со своей страной. Вместе с тем, защита жизни - это не просто повышение комплекса гарантий по обеспечению корзины экономических, социальных, политических, экологических прав человека, но и расширение поля возможностей развития и реализации каждым в общественно приемлемых формах. Для этого необходим подъём разнообразия во всём, дающий возможность самореализации: как внутри, так и вовне - в условиях разных коллективов, населённых пунктов и регионов. Однако движения обособления благополучных регионов для них коррелируют с вытягиванием потенциала из остального мира, для прочих же - ассоциируются с задачами самозащиты и развития.

Информационное взаимодействие выходит на авансцену экономического обмена, становясь как важным самостоятельным направлением общественных коммуникаций, так и весомым средством конкурентной борьбы. Акценты в ресурсно-методологических базах воздействия смещались в пользу то военно-политической, то экономической, то организационно-управленческой стратегии, усиливая ныне звучание информационной составляющей. Возрастание медийных эффектов означает и повышение общественной ответственности прессы. Негативным вирусом для развития даже базовых ценностно-смысловых комплексов культурно-цивилизационных миров может стать, например, дача оценок в зависимости от своих интересов (скажем, то «борцы за свободу», то «террористы»), фабрикация страхов, неумение слышать собственный народ, «гибкое отношение» к «пар- 
тиям социального возмущения» и т.п. [17-20].Тенденции гуманизации и демократизации структурирования общественных коммуникаций неминуемо выносят на первый план информационных отношений их социальный уровень, тесно связанный с базовыми ценностно-смысловыми комплексами культурно-цивилизационных миров. Результаты стратегической конкуренции при усилении роли общества знания поднимают значение развития и реализации в просоциальных направлениях научно-интеллектуального потенциала. Эффективные методы социально-экономического программирования процессов и самой постглобальной трансформации, и отдельных событий / тенденций во время форсированных изменений ориентируют на устойчивость и развитие качеств личности, меру взаиморезонирования социального и индивидуального выбора. Качество же как образования личности, так и участия в процессах обучения (а также самообучения и переобучения) коррелирует с повышением требований к социальной педагогике и социальному управлению.

\section{5. Выводы}

Мировая экономика испытывает не только общие со всей международной жизнью трансформации, но и специфические, в частности, характеризующие изменения структурирования как деятельности национальных хозяйств, так и глобальными процессами производства, распределения, обмена и потребления, отражающие кардинальные сдвиги в системообразующих отношениях труда, собственности и управления, прежде всего, в свойственных постглобальности направлении гуманизации и народовластия / демократизации.

Пребывание в пространстве стратегической неопределённости заканчивается. Вместе с тем, период увеличения удельного веса и значения хаоса - время установления нового порядка. Но вот каким он будет - вовсе не предрешено, так что противоборство за субъектность в переустройстве нарастает. Естественно, что время межпарадигмального перехода расширяет окно возможностей, обостряя требования к качеству принятия и исполнения организационно-управленческих решений. Предстоит выработать и согласовать механизмы защиты национальных интересов разнообразных субъектов, переформировать представления об общих гуманитарных стандартах при сохране- 
нии прав на собственный порядок жизнедеятельности, защите свобод человека при поддержании уклада.

Соответственно, мастерство сценарного планирования в организации управленческих композиций интеграции должно обеспечить и оптимизацию использования имеющейся ресурсной базы, и подстраховки (замещения) недоброкачественных элементов, а также тех, что выходят из строя. Поэтому гибкость, пластичность - необходимость обеспечения успешной общественной миссии в быстро трансформирующихся условиях социальной эклектики. Усиление роли государств - представителей идентичности культурно-цивилизационных миров позволяет препятствовать нагнетанию межпарадигмальной напряжённости и расползанию хаоса без создания линий раскола; напротив, именно признание различий создаёт надёжное основание для взаимозаинтересованности, в т.ч. в сфере международных экономических отношений. Кроме того, это позволяет освободить население от рутины мелких хлопот для разнообразия поисков нового и творческой активности. Если государства - лидеры соответствующих культурно-цивилизационных миров приступили к «сборке будущего» соответственно своим ценностно-смысловым комплексам и представлениям о достойном и желательном, то для остальных задачи, скорее, приобретают характер использования формирующихся тенденций для наиболее полной из возможных в этих условиях реализаций собственных национальных интересов. Отказ от принципа нерушимости границ, проявившийся, в частности, в разделе Югославии, усилил предпосылки и дал мощный толчок большому переструктурированию и новому дроблению / собиранию сил. Созданы международные прецеденты, важные при противоречиях в реализации прав на самоопределение населением частей прежних государств.

Заметно, что ныне в первую очередь, оригинальные комплексные подходы пытаются репрезентовать и отстоять носители государственности ядра культурно-цивилизационных миров, например, Китай, Индия, США, РФ и др. В данный момент Украина не перенимает полностью ни одну из лидерских систем. Более того, её вхождение в любую из них несёт столь серьёзный дополнительный потенциал изменений каждой, что это может и обогатить, и разрушить базовую модель. Соответственно, в элитах всяких лидерских групп существуют 
весомые опасения и ни в одной из них нет желания прямого включения Украины, но есть в той или иной форме желания манипулирования ею. В восприятии нового на перепутье нравственность народа и политика элиты, качество институтов и лидеров тесно связаны. Стремление части населения стран из «бывшего лагеря реального социализма» вхождения их государств в «золотой миллиард» не только беспочвенно и иллюзорно, но и мешает обретению и культивированию собственных, оптимальных в данной общественной среде, структурных форм развития и безопасности.

\section{Список литературы:}

1. Гидденс Э. Последствия современности. Москва: Праксис, 2011. 352 с.

2. Гэмбл Э. Кризис без конца? Крах западного процветания. Москва : Изд. дом ВШЭ, 2018. 304 с.

3. Шедяков В.Е. Развитие международных экономических отношений в эпоху постглобализма. Innovative Potential of Socio-Economic Systems: the Challenges of the Global World: Proceed. of III Intern. Scient. Conf. Lisbon, December $28^{\text {th }}$, 2018. P. 11-13.

4. Геєць В. М. Довіра як елемент соціального капіталу в економічному розвитку України. Економічна теорія. № 3. 2010. С. 7-19.

5. Шедяков В. Е. Взаимосвязь фундаментального и актуального уровней в осуществлении устойчивого социально-экономического развития. Розвиток економіки України: трансформащії та інноващії / заг. ред. О.Л. Гальцової. Запоріжжя: Гельветика, 2017. Т. 2. С. 34-48.

6. Шедяков В. Е. Место социальной ответственности в обеспечении продуктивной основы реализации общественных интересов. Соиіальна відповідальність влади, бізнесу і громадян / заг. ред. Г.Г. Півняка; М-во освіти і науки України; Нац. гірн. ун-т. Д.: НГУ, 2014. Т. 1. С. 282-290.

7. Shedyakov V. Social partnership in the system of organization of the social environment of effective competitiveness management. Conceptual aspects management of competitiveness the economic entities / ed. by M. Bezpartochnyi, I. Britchenko; Higher School of Social and Economic. Przeworsk : WSSG, 2019. Vol. 2. P. 222-239.

8. Бек У. Общество риска. На пути к другому модерну. Москва : ПрогрессТрадиция, 2000. 384 с.

9. Шедяков В. С. Трансформації міжнародних економічних відносин як фактор удосконалення інтеграційних процесів. Економіст. 2014. № 11. С. 14-19.

10. Шедяков В. Е. Геостратегические трансформации как политико-экономическая среда организационных изменений. Проблеми системного підходу в економіиі. 2019. № 1(69). Ч. 1. С. 16-24.

11. Shedyakov V. Economics of development or dying away: the role of social and information technologies. Development of modern science: the experience 
of European countries and prospects for Ukraine. Riga: Baltija Publishing, 2019. P. 289-307.

12. Шедяков В. Е. Политико-экономическая стратегия форсированных трансформаций. Strategies for Economic Development: The experience of Poland and the prospects of Ukraine / ed. by A. Pawlik, K. Shaposhnykov. Kielce : Baltija Publishing, 2018. Vol. 1. P. 287-303.

13. Shedyakov V. Creation and realization of organizational-management strategy during paradigm transformation. Organizational-economic mechanism of management innovative development of economic entities / ed. by M. Bezpartochnyi. Przeworsk : WSSG, 2019. Vol. 3. P. 345-364.

14. Шедяков В. Е. Организационно-управленческие ресурсно-методологические возможности обеспечения конкурентоспособности. Theoretical and practical aspects of the development of modern science: the experience of countries of Europe and prospects for Ukraine / scient. ed. \& project dir. A. Jankovska. Riga : Baltija Publishing, 2018. Part 1. P. 495-517.

15. Шедяков В. Є. Стратегічна культура проведення трансформацій: можливості та загрози. Розвиток економіки України під впливом економічних, сочіальних, технологічних та екологічних трендів / ред. М.С. Пашкевич, Ж.К. Нестеренко; М-во освіти і науки України, Запор. нац. техн. ун-т, Нац. гірн. ун-т. Д. : НГУ, 2015. С. 30-41.

16. Шедяков В. Е. Осуществление парадигмальных трансформаций: сорезонирование стратегии, тактики и оперативного искусства в управленческих композициях. Development and modernization of social sciences: experience of Poland and prospects of Ukraine / Maria Curie-Sklodowska University. Lublin : Baltija Publishing, 2017. P. 282-307.

17. Большаков В.В. Агрессия против разума. Москва : Молодая гвардия, 1984. $256 \mathrm{c}$.

18. Аронсон Э., Пратканис Э. Современные технологии влияния и убеждения. Эпоха пропаганды. СПб. : Прайм-ЕВРОЗНАК, 2008. 543 с.

19. Шедяков В. Е. Информационное давление на нынешнем этапе конкуренции культурно-цивилизационных миров. Вестник Прикамского соииального института. 2018. № 2(80). С. 176-184.

20. Шедяков В.Е. Социальный уровень информационного влияния: стратегическая культура и управленческие композиции. Social sciences: development prospects in countries of Europe at the beginning of the third millennium / Economics College in Stalowa Wola. Riga : Baltija Publishing, 2018. C. 157-174.

\section{References:}

1. Giddens E. (2011). Posledstviya sovremennosti [The consequences of modernity]. Moscow : Praksis (in Russian)

2. Gembl E. (2018). Krizis bez kontsa? Krakh zapadnogo protsvetaniya [Crisis without end? The collapse of Western prosperity]. Moscow: VShE (in Russian)

3. Shedyakov V.E. (2018). Razvitie mezhdunarodnykh ekonomicheskikh otnosheniy v epokhu postglobalizma [The development of international economic 
relations in the era of post-globalism]. Innovative Potential of Socio-Economic Systems: the Challenges of the Global World: Proceed.of III Intern. Scient. Conf. Lisbon, December $28^{\text {th }}$, pp. 11-13.

4. Ghejecj V.M. (2010). Dovira jak element socialjnogho kapitalu v ekonomichnomu rozvytku Ukrajiny [Trust as an element of social capital in the economic development of Ukraine]. Economic theory, no 3, pp. 7-19.

5. Shedyakov V.E. (2017). Vzaimosvyaz' fundamental'nogo i aktual'nogo urovney $\mathrm{v}$ osushchestvlenii ustoychivogo sotsial'no-ekonomicheskogo razvitiya [Mutual connection between fundamental and current levels in the realization of sustainable socio-economic development]. Rozvytok ekonomiky Ukrajiny: transformaciji ta innovaciji [Economic Development of Ukraine: Transformation and Innovation]. Zaporizhzhja : Gheljvetyka, vol. 2, pp. 34-48.

6. Shedyakov V.E. (2014). Mesto sotsial'noy otvetstvennosti v obespechenii produktivnoy osnovy realizatsii obshchestvennykh interesov [The place of social responsibility in creation a productive basis for the realization of society's interests]. Socialjna vidpovidaljnistj vlady, biznesu i ghromadjan [Social responsibility of government, business and citizens]. D. : NGhU, vol. 1, pp. 282-290.

7. Shedyakov V. (2019). Social partnership in the system of organization of the social environment of effective competitiveness management. Conceptual aspects management of competitiveness the economic entities. Przeworsk: WSSG, vol. 2, pp. 222-239.

8. Bek U. (2000). Obshchestvo riska. Na puti k drugomu modernu [Society of risk. On the way to another modernity]. Moscow: Progress-Traditsiya (in Russian)

9. Shedyakov V.E. (2014). Transformaciji mizhnarodnykh ekonomichnykh vidnosyn jak faktor udoskonalennja integhracijnykh procesiv [Transformation of international economic relations as a factor of improving of integration processes]. Economist, no 11, pp. 14-19.

10. Shedyakov V.E. (2019). Geostrategicheskie transformatsii kak politikoekonomicheskaya sreda organizatsionnykh izmeneniy [Geostrategic transformations as a political and economic environment for organizational change]. Problems of systematic approach in economy, no. 1(69), part 1, pp. 16-24.

11. Shedyakov V. (2019). Economics of development or dying away: the role of social and information technologies. Development of modern science: the experience of European countries and prospects for Ukraine. Riga: Baltija Publishing, pp. 289-307.

12. Shedyakov V.E. (2018). Politiko-ekonomicheskaya strategiya forsirovannykh transformatsiy [Political and economic strategy of forced transformations]. Strategies for Economic Development: The experience of Poland and the prospects of Ukraine. Kielce: Baltija Publishing, vol. 1, pp. 287-303.

13. Shedyakov V. (2019). Creation and realization of organizational-management strategy during paradigm transformation. Organizational-economic mechanism of management innovative development of economic entities. Przeworsk: WSSG, vol. 3, pp. 345-364.

14. Shedyakov V.E. (2018). Organizatsionno-upravlencheskie resursnometodologicheskie vozmozhnosti obespecheniya konkurentosposobnosti 
[Organizational and managerial resource and methodological capabilities to ensure competitiveness]. Theoretical and practical aspects of the development of modern science: the experience of countries of Europe and prospects for Ukraine. Riga: Baltija Publishing, part 1, pp. 495-517.

15. Shedyakov V.E. (2015). Strateghichna kuljtura provedennja transformacij: mozhlyvosti ta zaghrozy [Strategic Transformation Culture: Opportunities and Threats]. Rozvytok ekonomiky Ukrajiny pid vplyvom ekonomichnykh, socialjnykh, tekhnologhichnykh ta ekologhichnykh trendiv [Economic Development of Ukraine under the Influence of Economic, Social, Technological and Environmental Trends]. D.: NGhU, pp. 30-41.

16. Shedyakov V.E. (2017). Osushchestvlenie paradigmal'nyh transformatcyi: sorezonirovanie strategii, taktiki I operativnogo iskusstva $\mathrm{v}$ upravlentcheskih kompozitciyah [Realization of paradigm transformations: co-resonance of strategy, tactics and operational art in managerial compositions]. Development and modernization of social sciences: experience of Poland and prospects of Ukraine. Lublin: Baltija Publishing, pp. 282-307.

17. Bol'shakov V.V. (1984). Agressiya protiv razuma [Aggression against the mind]. Moscow: Molodaya gvardiya. (in Russian)

18. Aronson E., Pratkanis E. (2008). Sovremennye tekhnologii vliyaniya $i$ ubezhdeniya. Epokha propagandy [Modern technologies of influence and persuasion. The era of propaganda]. SPb.: Praym-EVROZNAK. (in Russian)

19. Shedyakov V.E. (2018). Informatsionnoe davlenie na nyneshnem etape konkurentsii kul'turno-tsivilizatsionnykh mirov [Information pressure at the current stage of competition of cultural and civilizational worlds]. Bulletin of the Prikamsky Social Institute, no 2(80), pp. 176-184.

20. Shedyakov V.E. (2018). Sotsial'nyy uroven' informatsionnogo vliyaniya: strategicheskaya kul'tura i upravlencheskie kompozitsii [Social level of informational influence: strategic culture and managerial compositions]. Social sciences: development prospects in countries of Europe at the beginning of the third millennium. Riga: Baltija Publishing, pp. 157-174. 